\title{
Study on Personal Socio-Agro-Economic, Psychological and Communicational Characteristics of the Vegetable Growers in Western Uttar Pradesh, India
}

\author{
${ }^{1}$ S.V.P.U.A. \& T, Meerut, India \\ ${ }^{2}$ K.V.K, Saharanpur, India \\ ${ }^{3}$ IARI, New Delhi, India \\ *Corresponding author
}

Dan Singh $^{1 *}$, D.K. Singh ${ }^{1}$, R.N. Yadav ${ }^{1}$, Satya Prakash ${ }^{2}$ and Kumari Shanti ${ }^{3}$

\begin{abstract}
A B S T R A C T
The present study was conducted in Saharanpur and Hapur district to know the personal socio - agro economic, psychological and communicational characteristics of the vegetable growers. It was found that majority of $87.50 \%$ vegetable growers belongs to the Keywords age group of $25-50$ years, $80 \%$ belongs to OBC category, $40.63 \%$ middle school passed, 98.12\% married, $86.25 \%$ jointly living, $73.75 \%$ family having $5-8$ members in a family, $83.75 \%$ having own land for cultivation, $45.62 \%$ belongs to small land holding size, Vegetable growers and characteristics. $50.63 \%$ farmers having 2- 4 milch animals, $100 \%$ having electricity at home,57.50\% farmers having jhota buggy for loading, $73.12 \%$ having two wheeler transport facilities, $52.50 \%$ farmers belongs to income group of fifty thousand to 1 lac per annual. The vegetable growers 35.41 percent were agree of the risk bearing statement, followed by 23.435 percent vegetable growers were strongly agree of the risk bearing statements, 50.63 percent vegetable growers were taking medium level of risk in vegetable cultivation, followed by 30.00 percent vegetable growers were taking low level risk in vegetable cultivation. In institutional source of communication the KrishiVigyan Kendra / University scientists was ranked $1^{\text {st }}$ in credibility, in group approach demonstration ranked in $1^{\text {st }}$, in mass communication media television ranked in $1^{\text {st }}$ and non-institutional/informal communication source friends was ranked $1^{\text {st }}$ in credibility of the farmers opinion.
\end{abstract}

\section{Introduction}

India is the second largest producers of vegetables in the world next to china with 2.8 per cent of total cropped area under vegetables. The total cultivated area of vegetables in India was 9542.23 thousand ha and production was of 169478.23 thousand million tones in 2014-15. Our country has progressed significantly during the past six decades in developing high yield verities/hybrids of different vegetables with their improved qualities and standardized agro techniques suitable for different agro-climatic conditions. Out per capita consumption has increased from 80-175 g/day.

However the present per capita consumption of vegetables per day is only $175 \mathrm{~g}$. Which is below the recommended requirement of 300 g. keeping in view the above facts, our aimed is to study the personal socio - agro economic, psychological and communicational characteristics of the vegetable growers in Western Uttar Pradesh. 


\section{Research Methodology}

For the investigation two district Saharanpur and Hapur were selected on the basis of maximum and minimum area, production and productivity of vegetables. From each district two blocks were selected i.e. Baliyakheri and Rampur Maniharan from Saharanpur and Hapur block and Dhaulana block from Hapur district. From each block four villages were selected purposively. Thus total 16 villages were selected. The total sample size was of 160 vegetable growers for the investigation. The survey work was conducted in the month of November, December 2014, and January 2015 through personal interview with the help of survey schedule. After analysis of the data find out the percentage, credibility index and rank order.

\section{Results and Discussion}

The data presented in table 1 , reveals that the majority of 87.50 percent vegetable growers were belonging to age of 25-50 years, followed by 8.12 percent were belonging to age to above 50 year and the remaining 4.38 percent were belonging to age of up to 25 years. The majority of 80.00 percent belonging to the other backward caste, 15.00 percent belongs to general caste, 3.13 percent belongs to schedule caste /schedule tribe caste and the remaining 1.87 percent belongs to minority caste as like Muslim and Shikkha. The majority of 42.50 percent vegetable growers educated to middle school, 30 percent up to high school, 15.00 percent up to intermediate, 10.00 percent up to graduate and above and the remaining 1.87 percent vegetable growers were not educated. 98.12 percent respondents were married and the remaining 1.87 percent unmarried.

The majority of 86.25 percent vegetable growers were living in joint-family system and the remaining 13.75 percent were living in nuclear family system. The majority of 73.75 percent respondents were belonging to the medium size of family i.e. 5-7 members. The majority of 86.87 percent respondents main occupation were farming, followed by 10.00 percent respondents main occupation were farming business and the remaining 3.13 percent respondents had main occupation farming and service. 7.63 percent respondents were participating gram panchayat- activities followed by 10.00 percent respondents were participating sugar cane activities, 7.50 percent cooperative activities, 6.88 percent krishivigyankendras/university activities and the remaining 5.00 percent respondent were participating state government department activities. The data regarding Agro-economic characteristics of the vegetable growers presented in table 2, reveals that the majority of 83.75 percent vegetable growers were having own land for cultivation of vegetables and the remaining 16.25 vegetable growers had rented land for vegetable cultivation.

The majority of 45.62 percent vegetable growers were belonging to small farmers categories followed by 9.37 percent vegetable growers were belonging to medium category farmers, 7.50 percent semi-medium farmers category. 3.50 percent vegetable growers belong to marginal farmers category and the remaining 2.50 percent farmers were belong to the large farmers categories. The majority of 50.63 percent respondent were having 2-4 milch animals, followed by 35.62 percent respondent were having more than 4 milch animals and the remaining 13.75 percent respondent had 1-2 milch animal for milk purpose. 51.25 percent respondents were reporting that above 10 liter milk production per day at their home followed by 41.25 percent respondents were reporting 5-10 liter milk production per day at their home and the remaining 7.50 percent respondents were reporting below 5 liter milk production per 
day at their home. 100 percent respondents were having electricity at their home and 16.25 percent respondents had electricity at their farm.

The majority of 73.13 percent respondents were having two wheeler for transport followed by 26.87 percent were having four wheeler for transport facility and 22.50 percent had both (two wheeler as well as four wheeler) the majority of 57.50 percent respondent were having Jhotabuggi for loading followed by 21.88 percent having tractor trolley for loading, 1.25 percent respondent were having Jugar for loading purpose and 19.37 percent respondent were not having any transport facilities for loading of vegetables. The majority of 52.50 percent respondent were belonging the annual income group up to Rs. 50,000- 1,00,000 followed by, 26.87 percent respondents belongs to annual income up to Rs. 50,000, 11.87 percent belongs to Rs. 1-1.5 lakh and the remaining 8.76 percent respondents were having annual income of Rs. 1.5 lakh.

The data regarding psychological characteristics presented in table 3 reveals that the level of agreements of vegetable growers were found more in statement of a vegetable growers should rather take more chance to have a big profit than to be intent with un risky smaller profit it was rank in $\mathrm{I}^{\text {st }}$. The level of agreement vegetable growers were found in $\mathrm{II}^{\mathrm{nd}}$ place of the statement, training entirely new packages of practices of vegetable growers through involves risk, but it worthwhile and it was rank in II $^{\text {nd }}$

The level of agreement of vegetable growers were found in III $^{\text {rd }}$ place of the statement it is a good for vegetable growers to take risk when he knows that his chance of his profit fairly high and it was rank in III ${ }^{\text {rd }}$. The level of agreement of the vegetable growers were found in $\mathrm{IV}^{\text {th }}$ place of the statement a vegetable growers should start more enterprises to avoid greater risk involved in starting one or two enterprise and its was rank in $\mathrm{IV}^{\mathrm{th}}$. The level of agreement of the vegetable grower were found in $\mathrm{V}^{\text {th }}$ place of the statement, it is better for a vegetable growers not to adopt new package of practices unless to be proved better by other and it was rank in $\mathrm{V}^{\text {th }}$. The level of agreement of vegetable growers were found in $\mathrm{VI}^{\text {th }}$ palace of the statement of a vegetable grower who is willing to take greater risk than the average farmers usually does better financially and it was rank in $\mathrm{VI}^{\text {th }}$.

The data presented in table 3 , indicated that 35.415 percent vegetable growers were agree of the risk bearing statement, followed by 23.435 percent vegetable growers were strongly agree of the risk bearing statements, 30.733 percent vegetable growers were neutral regarding the statements of risk beating, 7.603 percent vegetable growers were disagree of the risk beating statements and the remaining 2.811 percent vegetable growers were strongly disagree of the risk beating statements regarding vegetable.

It is obvious from the table 4 , the 50.63 percent vegetable growers were taking medium level of risk in vegetable cultivation, followed by 30.00 percent vegetable growers were taking low level risk in vegetable cultivation and the remaining 19.37 percent vegetable growers had high level of risk bearing in vegetable cultivation.

\section{Communicational characteristics of the vegetable growers}

The source of information used by the vegetable growers in the study area were identified and divided into three categories i.e. institutional media, group approach, mass media and non-institutional. 
Table.1 Personal socio -economic characteristics of the vegetable growers

\begin{tabular}{|c|c|c|c|}
\hline S.No. & Particular (Variables) & \begin{tabular}{|l|} 
No. of respondent \\
\end{tabular} & Percentage \\
\hline 1. & \begin{tabular}{|l} 
Age- \\
(i) $18-25$ years \\
(ii) $25-50$ year \\
(iii) above 50 year
\end{tabular} & $\begin{array}{l}07 \\
140 \\
13\end{array}$ & $\begin{array}{l}04.38 \\
87.50 \\
08.12\end{array}$ \\
\hline 2. & \begin{tabular}{|l} 
Caste- \\
(i) General \\
(ii) OBC \\
(iii) SC/ST \\
(iv) Minority
\end{tabular} & $\begin{array}{l}24 \\
128 \\
05 \\
03\end{array}$ & $\begin{array}{l}15.00 \\
80.00 \\
03.13 \\
01.87\end{array}$ \\
\hline 3. & $\begin{array}{l}\text { Education- } \\
\text { (i) Illiterate } \\
\text { (ii) Literate } \\
\text { (iii) Middle school } \\
\text { (iv)High school } \\
\text { (v) Intermediate } \\
\text { (vi) Graduation and above }\end{array}$ & $\begin{array}{l}03 \\
157 \\
68 \\
48 \\
25 \\
16\end{array}$ & $\begin{array}{l}01.87 \\
98.13 \\
42.50 \\
30.00 \\
15.63 \\
10.00\end{array}$ \\
\hline 4. & $\begin{array}{l}\text { Marital status: } \\
\text { (i)Married } \\
\text { (ii) Unmarried }\end{array}$ & $\begin{array}{l}157 \\
03\end{array}$ & $\begin{array}{l}98.12 \\
01.87\end{array}$ \\
\hline 5. & $\begin{array}{l}\text { Type of families- } \\
\text { (i) Joint family } \\
\text { (ii) Nuclear family }\end{array}$ & $\begin{array}{l}138 \\
22\end{array}$ & $\begin{array}{l}86.25 \\
13.75\end{array}$ \\
\hline 6. & $\begin{array}{l}\text { Size of family- } \\
\text { (i) Small (1 to } 4 \text { member) } \\
\text { (ii) Medium (5 member) } \\
\text { (iii) Large and above ( } 08 \text { me) }\end{array}$ & $\begin{array}{l}13 \\
118 \\
29\end{array}$ & $\begin{array}{l}08.12 \\
73.75 \\
18.12\end{array}$ \\
\hline 7. & $\begin{array}{l}\text { Occupation- } \\
\text { (i)Farming } \\
\text { (ii) Farming + Business } \\
\text { (iii) Farming+ Service }\end{array}$ & $\begin{array}{l}139 \\
16 \\
05\end{array}$ & $\begin{array}{l}86.87 \\
10.00 \\
03.13\end{array}$ \\
\hline 8. & \begin{tabular}{|l|} 
Institutional activity - \\
(i) Gram Panchayat activities \\
(ii) State Govt. activities \\
(iii) KVK/Uni. \\
(iv) Cooperative society \\
(v) Sugarcane Society \\
\end{tabular} & $\begin{array}{l}113 \\
8 \\
11 \\
12 \\
16\end{array}$ & $\begin{array}{l}70.62 \\
05.00 \\
06.88 \\
07.50 \\
10.00 \\
\end{array}$ \\
\hline
\end{tabular}


Table.2 Agro-economic characteristics of the vegetable growers

\begin{tabular}{|c|c|c|c|}
\hline S.No. & Particular (Variables) & \begin{tabular}{|l} 
No. of respondent \\
\end{tabular} & Percentage \\
\hline 1. & $\begin{array}{l}\text { Information regarding land: } \\
\text { (i) Landless } \\
\text { (ii) Rented land } \\
\text { (iii) Own land }\end{array}$ & $\begin{array}{l}0 \\
26 \\
134\end{array}$ & $\begin{array}{l}00.00 \\
16.25 \\
83.75\end{array}$ \\
\hline 2. & $\begin{array}{l}\text { Size of land holding: } \\
\text { (i) Marginal }(0-2.5 \text { acre) } \\
\text { (ii) Small ( } 2.5-5.0 \text { acre) } \\
\text { (iii) Semi- medium }(5-10 \text { acre) } \\
\text { (iv) Medium (10-20 acre) } \\
\text { (v) Large (above } 25 \text { acre) }\end{array}$ & $\begin{array}{l}56 \\
73 \\
12 \\
15 \\
04\end{array}$ & $\begin{array}{l}03.50 \\
45.62 \\
07.50 \\
09.37 \\
02.50\end{array}$ \\
\hline 3. & $\begin{array}{l}\text { Love Stock: } \\
\text { (i) No. of milch animal (1-2) } \\
\text { (ii) No. of milch animal (2-4) } \\
\text { (iii) No. of milch animal (above 4) }\end{array}$ & $\begin{array}{l}22 \\
81 \\
57 \\
\end{array}$ & $\begin{array}{r}13.75 \\
50.63 \\
35.62 \\
\end{array}$ \\
\hline 4. & $\begin{array}{l}\text { Production of milk/day: } \\
\text { (i) Below (5) L } \\
\text { (ii) Below(5-10)L } \\
\text { (iii) Above 10 L } \\
\end{array}$ & $\begin{array}{l}12 \\
66 \\
82 \\
\end{array}$ & $\begin{array}{l}07.50 \\
41.25 \\
51.25 \\
\end{array}$ \\
\hline 5. & $\begin{array}{l}\text { Electricity: } \\
\text { (i) Not at home } \\
\text { (ii) At home } \\
\text { (iii) At Farm } \\
\text { (iv) At home+Farm }\end{array}$ & $\begin{array}{l}0 \\
160 \\
26 \\
05\end{array}$ & $\begin{array}{l}00.00 \\
100.00 \\
16.25 \\
16.25\end{array}$ \\
\hline 6. & $\begin{array}{l}\text { Transport facilities: } \\
\text { (i) Two wheeler } \\
\text { (ii) Four wheeler } \\
\text { (iii) Both(A+B) } \\
\end{array}$ & $\begin{array}{l}117 \\
43 \\
36 \\
\end{array}$ & $\begin{array}{l}73.13 \\
26.87 \\
22.50\end{array}$ \\
\hline 7. & $\begin{array}{l}\text { Transport facilities (Loading): } \\
\text { (i) No transport facilities } \\
\text { (ii) Jhota Buggy } \\
\text { (iii) Tractor Trolley } \\
\text { (iv) Jugar }\end{array}$ & $\begin{array}{r}31 \\
92 \\
35 \\
2\end{array}$ & $\begin{array}{r}19.37 \\
57.50 \\
21.88 \\
1.25\end{array}$ \\
\hline 8. & $\begin{array}{l}\text { Annual income: } \\
\text { (i) Upto } 50,000 \\
\text { (ii)Upto } 50,000-1,00000 \\
\text { (iii) } 1,00000-1,50000 \\
\text { (iv) above } 1,50000\end{array}$ & $\begin{array}{l}43 \\
84 \\
19 \\
14\end{array}$ & $\begin{array}{l}26.87 \\
52.50 \\
11.87 \\
08.76\end{array}$ \\
\hline
\end{tabular}


Table.3 Psychological characteristics: risk bearing of the vegetable growers

\begin{tabular}{|l|l|l|l|l|l|}
\hline Statements & S.A(\%) & $\mathbf{A}(\boldsymbol{\%})$ & $\mathbf{U . D}(\boldsymbol{\%})$ & D.A.(\%) & S.D. $(\boldsymbol{\%})$ \\
\hline $\begin{array}{l}\text { i. A vegetable grower should start more enterprises } \\
\text { to avoid greater risk involved in starting one or } \\
\text { two enterprise }\end{array}$ & 20.00 & 35.00 & 28.12 & 10.00 & 6.87 \\
\hline $\begin{array}{l}\text { ii. A vegetable grower should rather take more } \\
\text { chance to have a big profit than to be intent with } \\
\text { un risky smaller profit }\end{array}$ & 34.37 & 34.37 & 25.63 & 5.00 & 0.63 \\
\hline $\begin{array}{l}\text { iii. A vegetable grower who is willing to take } \\
\text { greater risks than the average farmers usually does } \\
\text { better financially. }\end{array}$ & 18.75 & 28.12 & 40.63 & 8.75 & 3.75 \\
\hline $\begin{array}{l}\text { iv. It is a good for vegetable grower to take greater } \\
\text { risk when he knows that his chance of his profit } \\
\text { fairly high. }\end{array}$ & 18.12 & 45.00 & 29.38 & 6.25 & 1.25 \\
\hline $\begin{array}{l}\text { v. It is a better for a vegetable grower not to adopt } \\
\text { new package of practices unless to be proved } \\
\text { better by others. }\end{array}$ & 19.37 & 31.25 & 35.63 & 10.00 & 3.75 \\
\hline $\begin{array}{l}\text { vi. Trying entirely new packages of practices of } \\
\text { vegetable growers through involves risk, but it is } \\
\text { worthwhile }\end{array}$ & 30.00 & 38.75 & 25.00 & 5.62 & 0.62 \\
\hline Overall Average(rounded off to 2 decimal) & $\mathbf{2 3 . 4 4}$ & $\mathbf{3 5 . 4 2}$ & $\mathbf{3 0 . 7 3}$ & $\mathbf{7 . 6 0}$ & $\mathbf{2 . 8 1}$ \\
\hline
\end{tabular}

Table.4 Level of risk beating of the vegetable growers

\begin{tabular}{|l|l|c|c|}
\hline S.N. & Level & frequency & Percentage \\
\hline 1. & Low Level $<6.67$ & 48 & 30.00 \\
\hline 2. & Medium $(6.67-13.33)$ & 81 & 50.63 \\
\hline 3. & High Level $>13.33$ & 31 & 19.37 \\
\hline
\end{tabular}

Table.5 Communicational characteristics of the vegetable growers

\begin{tabular}{|l|c|c|c|c|}
\hline (a). Institutional information sources & $\begin{array}{c}\text { Most trust } \\
\text { worthy }\end{array}$ & $\begin{array}{c}\text { Least trust } \\
\text { worthy }\end{array}$ & $\begin{array}{c}\text { Relative } \\
\text { credibility index }\end{array}$ & Ranks \\
\hline Source: (villagers/farmers) & 55 & 105 & 0.33 & V \\
\hline (i) District Horticulture Officer's & 63 & 97 & 0.41 & III \\
\hline $\begin{array}{l}\text { (ii) Horticulture Extension Officer's/SMS } \\
\text { Horticulture }\end{array}$ & 58 & 102 & 0.36 & IV \\
\hline $\begin{array}{l}\text { (iii) Agriculture Development Officer's/Sub } \\
\text { Divisional Extn. Officer }\end{array}$ & 78 & 82 & 0.59 & II \\
\hline $\begin{array}{l}\text { (iv) Village Development Officer's/Kisan } \\
\text { Sahayak }\end{array}$ & 89 & 71 & 0.78 & I \\
\hline $\begin{array}{l}\text { (v) KrishiVigyan Kendra Scientist/ } \\
\text { University Scientist }\end{array}$ & 88 & 72 & 0.76 & III \\
\hline (b) Group approach & (i) Meeting's &
\end{tabular}




\begin{tabular}{|l|c|c|c|c|}
\hline (ii) Training's & 92 & 68 & 0.85 & II \\
\hline (iii) Demonstration's & 122 & 38 & 2.01 & I \\
\hline (iv) Field days & 92 & 68 & 0.85 & II \\
\hline (v) Farmers Interest Group/Self Help Group & 88 & 72 & 0.76 & III \\
\hline (c) Mass media & 114 & 46 & 1.55 & IV \\
\hline (i) Radio & 136 & 24 & 3.54 & I \\
\hline (ii) T.V. & 129 & 31 & 2.60 & II \\
\hline (iii) News papers & 115 & 45 & 1.60 & III \\
\hline (iv) Literature ( Leaflet / Folders / Pumplets / & \multicolumn{5}{|l|}{} & \\
Bulletins /Magazines) & 89 & 71 & 0.78 & VI \\
\hline (v) Farmers fairs/exhibitions & 95 & 65 & 0.91 & V \\
\hline (vi) Posters, Feature film & 113 & 47 & 1.64 & VI \\
\hline (d). Non Institutional/Informal sources & 119 & 41 & 1.81 & V \\
\hline (i) Neghbours & 137 & 23 & 3.72 & I \\
\hline (ii) Relatives & 133 & 27 & 3.08 & II \\
\hline (iii) Friends & 128 & 32 & 2.50 & IV \\
\hline (iv) Progressive farmers & 132 & 28 & 2.95 & III \\
\hline (v) Mitrakrashak/SamparkKrashak & & & & \\
\hline (vi) Input supply dealers & \multicolumn{5}{|l|}{} & & & \\
\hline
\end{tabular}

The relative credibility index of the source of information was worked out and the ranks were assigned accordingly.

The data presented in table 5, reveals that KVK/University scientists had the highest credibility (0.78), ranked in the first among the vegetable growers followed by VDOs/Kisan Shayak credibility (0.59), ranked in second, horticulture extension officers/SMS horticulture credibility $(0.41)$, ranked in III $^{\text {rd }}$, agriculture development officer/Sub divisional extension officers credibility $(0.36)$, ranked in $\mathrm{IV}^{\text {th }}$ and District Horticulture Officer credibility (0.33), ranked in $\mathrm{V}^{\text {th }}$ respectability.

The findings seem to be natural as the vegetable grower generally maintained more contacts with the VDOs/KisanSahayak, KVK/University scientists provided to the vegetable growers more accurate information on vegetable cultivation.

In group approach, demonstrations were found to be the most credibility (2.01), ranked in $\mathrm{I}^{\text {st }}$ source among all other sources, followed by trainings and filed days credibility (0.85), ranked in $\mathrm{II}^{\mathrm{nd}}$, meeting and farmers interested group/self help group credibility (0.76), ranked in III $^{\text {rd }}$ respectively.

Since demonstration is one most effective group approach for dissemination of agricultural innovations to be the farmers field with its motto of "Seeing believes". Hence H.D.O/H.E.O./ University and Scientists should arrange more and more field demonstrations at farmer's field.

In mass media, television was found to have most credibility (3.54), ranked in $\mathrm{I}^{\text {st }}$ among all the other sources of mass media like Newspaper credibility (2.60), ranked in II $^{\text {nd }}$ literature i.e., leaflet / Folder/Pamphlet/ Bulletin/Magazine credibility (1.60), ranked in third, radio credibility (1.53), ranked in $\mathrm{IV}^{\text {th }}$, Poster/feature film credibility (0.91), raked in $\mathrm{V}^{\text {th }}$ and farmers fair/exhibitions credibility (0.78), ranked in $\mathrm{VI}^{\text {th }}$, since television is the most effective mass media for dissemination of agriculture innovation to the farmers filed because television provide authentic information and respondent receive information from television by seeing and hearing. Among the noninstitutional sources of information, friends were found to be the most credibility (3.72), 
ranked in first, followed by progressive farmers credibility (3.08), ranked $\mathrm{II}^{\text {nd }}$, input supply dealers credibility (2.95), ranked III $^{\text {rd }}$, MitraKrishak/ Smparkkrishak credibility (2.50), ranked $\mathrm{IV}^{\text {th }}$, relative credibility source $(1.81)$, ranked $\mathrm{V}^{\text {th }}$ and Neighbors credibility source (1.64) ranked $\mathrm{VI}^{\text {th }}$ respectively. These findings were more or less similar to those of waghdare et al., (1998) who reported that agricultural assistant/ village extension workers, followed by neighbors/friend/relatives, progressive farmers/ local leaders and radio/T.V./Cinema were the most credibility sources of information by the vegetable growers.

Sharma et al., (2000) also found that Rural Agriculture Extension Officer, followed by friends, neighbors/progressive farmers, Radio/T.V. and Agricultural Scientists were the most important sources used by majority of the vegetable growers.

It can be concluded from the above study that the majority of vegetable grower belongs to the age group of 25-50 years, belongs to OBC category, middle school passed, married, jointly living, family having 5-8 members in a family, having own land for cultivation, belongs to small land holding size, farmers having 2-4 milch animals, having electricity at home, farmers having jhota buggy for loading, having two wheeler transport facilities, belongs to income group upto 1 lac per annual. The majority of vegetable growers were agree of the risk bearing statement, most of them taking medium level of risk in vegetable cultivation, In institutional source of communication the Krishi Vigyan Kendra/ University scientists was ranked $1^{\text {st }}$ in credibility, in group approach demonstration ranked in $1^{\text {st }}$, in mass communication media television ranked in $1^{\text {st }}$ and non-institutional/informal communication source friends was ranked $1^{\text {st }}$ in credibility of the farmers opinion.

\section{References}

Anonymous. 2014-15. Data Book of National Horticulture Board.

Bhople, D.D., P.S Sindhe and S.R. Bhople. 1998. Pattern of information by orange growers, Maharashtra J. Extension Education, XVII: 184-187.

Kumar, S., Singh, D. and Singh, R.P. 2007. Study on socio economic and psychological characteristics of potato growers in Meerut district of Uttar Pradesh. Raj. J. Ext. Edu., 10(1): 31-35.

Sharma, D.D. and Takur, S. 2005. Information management system among apple growers. Indian J. Extension Education, XXXXI (3\&4): 36-39.

Sharma, Rajnish, Singh, P.R. and R.N. Sharma. 2000. Utilization of farm information sources amongst triblas. Maharashtra J. Extension Education, XIX: 340-341.

Sindhu, A.S. 1973. Relative efficiency of farm methods. of measuring credibility of farm information sources, Indian J. Extension Education, XV(1\&2): 71:74.

Sonawane, Sangita, B., P.J. Chikhalikar and A.J. Nirban. 2001. Utilization of communication sources by the farmers for seeking farm information. Maharashtra J. Extension Education, XX: 61-62.

Waghdhara, K.W., Dupte, N.P. and P.V. Shinde. 1998. Information source credibility among small farmers. Maharashtra $J$. Extension Education, XVII: 52-54.

Yadav, R.N., Singh, D., Singh, V.K., Ali, N. and Yadav, S.P. 2008. Study on sociopsychological, socio-economical profile and constraints faced by thecole-crop growers in Meerut district of Western Uttar Pradesh. Progressive Res., 3(1): 21-34.

\section{How to cite this article:}

Dan Singh, D.K. Singh, R.N. Yadav, Satya Prakash and Kumari Shanti. 2017. Study on Personal SocioAgro-Economic, Psychological and Communicational Characteristics of the Vegetable Growers in Western Uttar Pradesh, India. Int.J.Curr.Microbiol.App.Sci. 6(7): 2255-2262. doi: https://doi.org/10.20546/ijcmas.2017.607.265 